\title{
Peran Notaris Dalam Pembagian Waris Berdasarkan Hak Waris Barat Dengan Peran Pengadilan Agama Dalam Pembagian Waris Berdasarkan Hak Waris Islam
}

\section{Setya Qodar Al-Haolandi', Danu Anindhito Kuncoro Putro**, Sukarmi**}

\author{
Mahasiswa Program Magister (S2) Kenotariatan Fakultas Hukum UNISSULA, Semarang email : \\ Setya.qodar@gmail.com \\ ** Mahasiswa Program Magister (S2) Ilmu Hukum, Fakultas Hukum UNISSULA, Semarang, e-mail: \\ danuanindito@gmail.com \\ *** Dosen Fakultas Hukum UNISSULA
}

\begin{abstract}
ABSTRAK
Penelitian ini bertujuan untuk mengetahui Peran Notaris dalam Pembagian Waris Barat dengan Peran Pengadilan Agama Dalam Pembagian Waris Islam. Untuk mengetahui kewenangan notaris dalam pembagian Waris berdasarkan Hukum Waris Barat dan Hukum Waris Barat. Metode penelitian yang digunakan dalam penelitian ini adalah yuridis empiris, sedangkann metode pengumpulann data yang digunakan adalah library research dengan mengumpulkan bahan-bahan hukum yang ada dilapangan dan wawancara. Metode analisa data dilakukan secara kualitatif kemudian disajikan secara deskriptif.

Penelitian ini menghasilkan pada pokoknya Kewenangan Pertanggung jawaban notaris dalam pembuatan akta wasiat wajibah atas bagian anak angkat tetap mengikuti ketentuan dalam pasal 16 UUJN Undang-Undang No 2 Tahun 2014 Tentang Jabatan Notaris. Pasal 16 UUJN ini membuat ketentuan tentang syarat-syarat bagi notaris dalam membentuk suatu akta, jika salah satu syarat sebagaimana dimaksud tidak dipenuhi, akta yang bersangkutan hanya mempunyai kekuatan pembuktian sebagai akta dibawah tangan. Notaris yang melanggar ketentuan tersebut dapat dikenai sanksi berupa peringatan tertulis, pemberhentian dengan tidak hormat. Selain dikenai sanksi tersebut pihak yang menderita kerugian untuk menuntut penggantian biaya, ganti rugi, dan jika terbukti notaris melakukan pelanggaran terhadap UUJN seperti memalsukan identitas para pihak, memalsukan tandatangan, maka notaris dapat dimintai pertanggung jawaban secara pidana. Anak angkat akan dapat memperoleh harta dari orangtua angkatnya berdasarkan wasiat yang besarnya tidak boleh melebihi $1 / 3$ (sepertiga) harta orang tua angkatnya yang telah meninggal dunia, bila orang tua angkatnya tidak meninggalkan wasiat maka dapat diberi berdasarkan wasiat wajibah, dan pemberi wasiat wajibah tidak boleh merugikan hakhak dari ahli waris. Kalau anak angkat mendapatkan bagian wasiat wajibah yang melebihi $1 / 3$ bagian, maka wasiat wajibah tidak batal demi hukum, melainkan harus dibatalkan dengan putusan pengadilan. Notaris memiliki kewenangan dalam pembagian waris islam tetapi menurut Notaris Sri Rochayati yang memiliki kewenangan penuh untuk menetapkan pengakuan secara hukum adalah pengadilan. Notaris dalam pembagian warisan berperan dalam pembuatan Akta Pernyataan Waris dan Surat Keterangan Hak Waris. Apabila terjadi sengketa, Notaris dapat membuatkan akta-akta perdamaian dan/atau perjanjian pelepasan hak tuntutan. Kewenangan notaris dalam pembagian waris hanya terbatas pada waris barat (BW) dan mengapa pembagian waris islam tidak ditugaskan kepada notaris. Notaris memiliki kewenangan dalam pembagian waris islam tetapi menurut Notaris Sri Rochayati yang memiliki kewenangan penuh untuk menetapkan pengakuan dan pemutusan secara hukum adalah pengadilan. Notaris dalam pembagian warisan berperan dalam pembuatan Akta Pernyataan Waris dan Surat Keterangan Hak Waris. Apabila terjadi sengketa, Notaris dapat membuatkan akta-akta perdamaian dan/atau perjanjian pelepasan hak tuntutan.

Kata kunci : Pembagian Waris, UUJN (Undang-Undang Jabatan Notaris), Kewenangan Notaris.
\end{abstract}

\section{ABSTRACT}

This study aims to determine the Role of Notaries in the Division of Western Heritage by the Role of Religious Courts in the Division of Islamic Inheritance. To know the authority of a notary in the division of Inheritance under the Law of the Western Heritage and the Law of the Western Heritage. The research method used in this study is empirical juridical, while the method of collecting data used is library research by collecting the existing legal materials in the field and interview. Data analysis method is done qualitatively then presented descriptively. 
This research resulted essentially Notary Accountability Authority in making deed of mandatory testament on the part of adopted children still follow the provisions in article 16 UUJN Act No. 2 Year 2014 About Notary's Position. Article 16 of the UUJN makes provisions on the terms of the notary in forming a deed, if one of the conditions referred to is not fulfilled, the deed concerned only has the evidentiary power as a deed under the hand. Notary who violates such provision may be subject to sanctions in the form of a written warning, dismissal of disrespect. In addition to the sanction, the party suffering losses to claim reimbursement of costs, compensation, and if the notary proves a violation of the UUJN such as falsifying the identity of the parties, falsifying the signature, the notary can be held criminally liable. The adopted child shall be able to obtain the property of his adoptive parent by a testament not exceeding $1 / 3$ (one third) of his adoptive parents' estate, if his adoptive parents have not left a will, then they may be given a mandatory will, and the donor shall not may harm the rights of the heirs. If the adopted child receives a mandatory part of the will exceeding $1 / 3$ of the part, the will is not void by law, but must be annulled by a court ruling. Notary has the authority in dividing the inheritance of Islam but according to Notary Sri Rochayati who has full authority to determine legal recognition is the court. Notaries in the distribution of inheritance play a role in the making of Deed of Inheritance Statement and Certificate of Rights of Inheritance. In the event of a dispute, a Notary may produce peace deeds and / or an agreement on the disposal of a claim. The authority of a notary in the division of inheritance is limited to the western heir (BW) and why the division of inheritance of Islam is not assigned to a notary. Notary has the authority in dividing the inheritance of Islam but according to Notary Sri Rochayati who has full authority to determine the recognition and termination legally is the court. Notaries in the distribution of inheritance play a role in the making of Deed of Inheritance Statement and Certificate of Rights of Inheritance. In the event of a dispute, a Notary may produce peace deeds and / or an agreement on the disposal of a claim.

Keywords: Division of Inheritance, UUJN (Position Notice Act), Notary Publicity

\section{PENDAHULUAN}

Permasalahan mengenai harta kekayaan dalam masyarakat menjadi salah satu faktor yang sangat vital. Tak ayal perselisihan yang terjadi karena adanya ketidak sepahaman mengenai pengurusan harta kekayaan. Mengenai harta kekayaan itu sendiri dapatlah berupa peristiwa hukum, yang kita kenal dengan warisan. Adanya pembagian harta kekayaan dikarenakan meninggalnya si pewaris yang mana harta kekayaannya akan jatuh kepada apara ahl waris yang berhak.

Harta kekayaan disini bukanlah hanya kepada mengenai warisan saja, tetapi segala proses yang terkait dengan harta kekayaan seseorang. Misalnya adanya proses jual beli yang membutuhkan balik nama, proses sewa menyewa, terjadinya wasiat, dan segala perbuatan dan peristiwa hukum lainnya.

Dalam kaitannya dengan hal tersebut, dirasakan perlunya peran pihak lain yang akan mengatur dan memberikan arahan kepada para pihak. Pihak lain ini sebagai pihak penengah antar pihak pertama dengan pihak kedua atau lebih. Dalam hal ini terbentuklah suatu lembaga yang dikenal dengan sebutan lembaga kenotariatan atau kita kenal dengan Notaris.

Seperti yang tertuang dalam Pasal 1 ayat (1) Undang-Undang Jabatan Notaris, Notaris adalah pejabat umum yang berwenang untuk membuat akata otentik dan kewenangan lainnya sebagaimana dimaksud dalam Undang-Undang ini. ${ }^{1}$ Pengertian ini bukanlah berarti peran Notaris hanya pada pembuatan akta saja, tetapi apabila kita melihat kewenangan, dan kewajiban Notaris yang tertuang dalam Pasal - pasal pada Undang-Undang Jabatan Notaris, kita akan memahami bahwa pada prosesnya Notaris berperan penting terhadap setiap peristiwa atau perbuatan hukum yang dikehendaki oleh para pihak untuk dibautkan aktanya oleh Notaris.

Hukum Perdata Barat yang terdapat dalam KUHPerdata adalah bersifat mengatur atau yang disebut "anvullenrecht", hal ini bermaksud bahwa sebenarnya tidak unsur paksaan harus diterapkannya ketentuan yang terdapat dalam KUHPerdata untuk diterapkan dalam permasalahan Kewarisan di Indonesia namun apabila mereka menginginkan untuk menggunakan KUHPerdata dalam penyelesaian Kewarisan mereka maka hal itu diperbolehkan. Karena dalam prakteknya demikian, Penulis hanya membatasi pembahasan mengenai Hukum Kewarisan selain Islam khusus hanya sebatas

\footnotetext{
${ }^{1}$ Undang-Undang Nomor 2 tahun 2014 perubahan Undang-Undang Nomor 30 Tahun 2004 Tentang Jabatan Notaris
} 
Hukum Kewarisan menurut KUHPerdata sebagaimana banyak digunakan dalam praktek.

Pembagian waris dengan menggunakan akta notaris adalah sebagai suatu alternatif cara pembagian warisan selain menggunakan institusi pengadilan yang mana biasa dipergunakan oleh masyarakat Indonesia di dalam pembagian warisan. Sama halnya dengan putusan pengadilan, akta yang dibuat notaris bertujuan sebagai penjelas pembagian warisan untuk mengantisipasi masalah-masalah yang mungkin saja muncul di depan. Berdasarkan hukum positif Indonesia ada beberapa cara dalam mendapatkan penetapan pembagian harta warisan. Pertama sebagaimana telah disebutkan yaitu melalui putusan pengadilan yang kedua adalah melalui notaris lewat pembagian akta pemisahan dan pembagian waris. Keduanya memiliki kekuatan hukum yang sama sehingga bila satu keluarga sudah mempunyai satu saja atau menggunakan salah satu cara saja maka kekuatan hukumnya sudah kuat. Kedua cara itu memiliki kekuatan hukum yang samasama kuat. Pasal 15 ayat (1) UUJN menjelaskan bahwa salah satu kewenangan Notaris, yaitu membuat akta secara umum, dengan batasan sepanjang: (a) Tidak dikecualikan kepada pejabat lain yang ditetapkan oleh undang-undang. (b) Masyarakat akta yang harus dibuat atau berwenang membuat akta otentik mengenai semua perbuatan, perjanjian, dan ketetapan yang diharuskan oleh aturan hukum atau dikehendaki oleh yang bersangkutan. (c) Mengenai subjek hukum (orang atau badan hukum) untuk kepentingan siapa akta itu dibuat atau dikehendaki oleh yang berkepentingan. (d) Berwenang mengenai tempat, dimana akta itu dibuat, hal ini sesuai dengan tempat kedudukan dan wilayah jabatan Notaris. (e) Mengenai waktu pembuatan akta, dalam hal ini Notaris harus menjamin kepastian waktu menghadap para penghadap yang tercantum dalam akta.

Dalam hal ini, Notaris sebagai salah satu pejabat umum yang mempunyai kewenangan membuat akta otentik dan kewenangan lain sebagaimana telah diamatkan padanya oleh Undang-Undang, maka iapun berperan terhadap kepentingan setiap warga masyarakat yang berkepentingan untuk membuat akta, tidak terlepas dari adanya kepentingan warga muslim yang ingin melakukan pengurusan terhadap Harta keayaannya.

\section{PEMBAHASAN}

\section{Peran Notaris dalam Pembagian Waris Anak Angkat berdasarkan Hukum Waris Barat dan Hukum Waris Islam di Indonesia.}

Peran notaris dalam pembagian hak waris barat yang dalam pembahasan ini pembagiannya di khususkan kepada anak angkat. Di dalam hukum waris barat (BW) seorang anak angkat bisa mendapatkan hak warisnya berdasarkan hibah wasiat. Diatur dalam pasal 957 KUHPerdata yang menyebutkan bahwa : "hibah wasiat adalah suatu penetapan wasiat yang khusus, dengan mana si yang mewariskan kepada seorang atau lebih memberikan beberapa barang-barangnya dari suatu jenis tertentu, seperti misal segala barang-barangnya bergerak atau tidak bergerak atau memberikan hak pakai hasil atas seluruh atau sebagian harta peninggalannya"

Jadi legaat (hibah wasiat) adalah suatu penetapan wasiat dengan mana pewaris memberikan kepada seorang/lebih :

1. Beberapa barang tertentu dari harta peninggalan

2. Memberikan barang-barang dari jenis tertentu

3. Memberikan hak pakai hasil atas seluruh / sebagian harta peninggalan .

Sedangkan pasal 968 KUHPerdata menyebutkan bahwa "hibah wasiat mengenai kebendaan tak tentu adalah dijinkan, baik si yang mewariskan meninggalkan kebendaan yang demikian atau tidak". Dari pasal ini terlihat bahwa hibah wasiat mengenai "barang-barang tidak tertentu" akan tetapi "dari sesuatu jenis tertentu" adalah mungkin, baik jika si pewaris telah meninggalkan barang-barang yang demikian itu ataupun tidak.

Jadi tidak diisyaratkan bahwa si pewaris mempunyai barang-barang tersebut, selain itu juga hak-hak kebendaan lain dari hak pungut hasil dapat diwariskan, misal pembebasan hutang. Menurut Opzoomer, keanehan hibah wasiat adalah orang yang menikmatinya tidak ada hubungan apa-apa dengan kesatuan harta warisan dan data pribadi si pewaris. Ia menerima sesuatu, mungkin banyak, mungkin sedikit, dari harta warisan. Meskipun demikian harta warisan itu sendiri sebagai kesatuan, tidak pindah kepadanya baik sebagai ataupun seluruhnya. Ia tidak menggantikan kedudukan si pewaris, melainkan hanya menerima saja sesuatu dari apa yang ditinggalkan si pewarsi, dari mereka yang benar-benar mengganti kedudukan si pewaris, yaitu para ahli waris. Legataris adalah kreditur dari para ahli waris. Selama warisannya belum terbagi 
maka legataris tidak usah mencari dan menuntut masing-masing ahli waris untuk bagiannya, haknya untuk menerima penyerahan legaatnya dipunyai terhadap seluruh warisan dan karena itu terhadap ahli waris bersama.

Testamen atau wasiat adalah pernyataan sesesorang tentang apa yang dikehendakinya setelah iya meninggal mengenai hartanya (sewaktu-waktu dapat berubah) selama pembuatnya masih belum meninggal dunia. Meskipun apa yang akan terjadi terhadap hartanya merupakan hak pewaris seutuhnya , tetapi masih ada batasan dalam undangundang perihal pembagian waris yang dapat di terima. Dalam pasal legitime portie yaitu bagian warisan yang sudah ditetapkan menjadi hak dari ahli waris dalam garis lencang yang tidak dapat di hapuskan oleh pewaris.

Isi dari testamen dapat berupa :

1. Menunjuk atau mengangkat seseorang menjadi anak angkat

2. Pemberian seseorang yang legat

Testamen sebetulnya tidak terbatas mengenai hal kekayaan saja. Melalui testamen juga sah dilakukan perbuatan, menunjukkan seseorang sebagai wali untuk anak-anak dari si meninggal, pengakuan terhadap anak yang lahir diluar pernikahan dan pengangkatan pelaksana wasiat yaitu orang yang dikuasaiuntuk mengawasi dan mengatur pelaksanaan testamen. Dimana kedudukan testamensama dengan kedudukan ahli waris.dia memperoleh kewajiban segala hak dan kewajiban (onder algemene title) dari si pewaris. Dia menggantikan si pewaris dalam segala hak dan kewajiban biasanya dalam hal testamen yang menunjuk lebih dari satu ahli waris, juga disebut dari beberapa bagian masing-masing seperempat bagian.

Pasal 907 BW : mengandung larangan yang ditujukan kepada notaris dan para saksi. Yang dimaksud dengan notaris disini adalah kewenangan notaris dalam membuat testamen yang bersangkutan dan saksi disini adalah saksi instrumentair sebagaimana yang dimaksud dalam pasal 22 peraturan Jabatan Notaris. ${ }^{2}$

Selanjutnya larangan pasal 907 BW : dipertegas didalam pasal 21 Peraturan Jabatan Notaris. Didalam peraturan Jabatan Notaris dibedakan menjadi 2 macam saksi didalam pembuatan akta notaris.

\footnotetext{
${ }^{2}$ Pasal 22 Peraturan Jabatan Notaris menyatakan bahwa

"Akta-akta Notaris, dibuat dihadapan Notaris, dengan dihadiri dua orang saksi" Pasal 21 P.J.N
}

Yang pertama adalah saksi attestatief. Saksi attestatief di perlakukan dalam akta notaris sehubungan dengan adanya ketentuan dalam pasal 24 peraturan jabatan notaris, bahwa orang yang menghadap -pada pembuatan akta harus dikenal oleh notaris atau di perkenalkan oleh 2 orang saks. Saksi yang memperkenalkan penghadap notaris disebut saksi pengenal atau saksi attestateif.

Yang kedua dalah saksi instrumentair.saksi ini adalah saksi sebagai yang di maksud oleh pasal 22 peraturan jabatan notaris yang merupakan saksisaksi yang harus hadir pada waktu pembuatan akta , yaitu mulai saat pembacaan sampai penandatangannya. Mereka bahka wajib turut menanda tangani akta tersebut dan turut menjaminkebenaran isi akta. Dalam proses verbal akta merekaa malahan harus hadir menyaksikanperbuatan-perbuatan dan tindakantindakan yang dilakukan oleh seorang notaris dan yang hadir pada waktu pembuatan akta proses verbaal. Yang terkena larangan pasal 907 b.w adalah saksi-saksi yang disebut terakhir.

Diatas sudah dijelaskan mengenai peran notaris dalam pembagian hak waris anak angkat menurut Hukum Waris Barat (BW). Dibawah ini penulis akan menjelaskan tentang Peran Notaris dalam pembagian waris anak angkat dalam Kompilasi Hukum Islam. Sebelumnya penulis akan menjelaskan bagaimana status dan kedudukan anak angkat dalam pandangan hukum islam.

Pengangkatan anak yang dilakukan oleh suatu keluaga untuk melanjutkan dan mempertahankan garis keturunan dalam suatu lingkungan keluarga yang tidak mempunyai anak kandung. Selain itu maksud dari pengangkatan anak disini adalah untuk mempertahankan ikatan perkawinan sehingga tidak timbul perceraian tetapi saat ini dengan adanya perkembangan motivasi dari pengangkatan anak kini telah berubah yakni demi kesejahteraan anak yang diangkat. Pengangkatan anak dewasa ini sering dilakukan oleh berbagai kalangan dalam masyarakat. Seseorang dalam mengangkat anak pasti memiliki tujuan yang ingin dicapai karena pada dasarnya banyak faktor yang mendukung seseorang melakukan pengangkatan anak, namun lazimnya latar belakang pengangkatan anak dilakukan oleh orang yang tidak diberi keturunan. Pengangkatan anak dilakukan guna memenuhi keinginan manusia untuk menyalurkan kasih sayangnya kepada anak 
yang dirasakan akan merupakan kelanjutan hidupnya. $^{3}$

Adapun syarat-syarat pengangkatan anak yang sesuai dengan hukum Islam adalah sebagai berikut:

1. Tidak memutuskan hubungan darah antara anak yang diangkat dengan orang tua kandung dan keluarganya.

2. Anak angkat tidak berkedudukan sebagai ahli waris dari orang tua angkat, melainkan tetap sebagai ahli waris dari orang tua kandungnya, demikian juga orang tua angkat tidak berkedudukan sebagai ahli waris dari anak angkatnya.

3. Hubungan kehartabendaan antara anak angkat dengan orang tua angkatnya hanya diperbolehkan dalam hubungan wasiat dan hibah.

4. Anak angkat tidak boleh mempergunakan nama orang tua angkatnya secara langsung kecuali sekedar sebagai tanda pengenal atau alamat.

5. Orang tua angkat tidak dapat bertindak sebagai wali dalam perkawinan terhadap anak angkatnya.

6. Antara anak yang diangkat dengan orang tua angkat seharusnya sama-sama orang yang beragama islam, agar sianak tetap pada agama yang dianutnya.

Motivasi pengangkatan anak dalam Islam adalah lebih kepada memberikan perlakuan dan menyalurkan rasa kecintaan serta kasih sayang kepada anak, pemberian nafkah, pendidikan, dan pelayanan segala kebutuhan, bukan memperlakukannya sebagai anak kandungnya sendiri dengan segala konsekuensi hukumnya. Islam mengarahkan kepada manusia agar selalu peduli kepada sesama, karena sikap peduli sesama merupakan suatu hal yang memang harus selalu diamalkan, terlebih lagi terhadap anak-anak terlantar dan anak yatim. Islam juga mengajarkan umatnya untuk selalu menyantuni dan memelihara anak-anak yang tidak mampu, miskin, terlantar, dimana perbuatan penyantunan dan pemeliharaan anakanak tersebut tidak sampai pada pemutusan hubungan keluarga dan hak-hak orang tua

\footnotetext{
${ }^{3}$ Ahmad Azhar Basyir, Kawin Campur, Adopsi, Wasiat Menurut Islam, (Bandung: AlMaa'rif, 1972), hlm. 19

${ }^{4}$ Muderis Zaini, Adopsi Suatu Tinjauan Tiga Sistem Hukum, (Jakarta: Sinar Grafika, 1995), hlm. 54
}

kandungnya dan pemeliharaan tersebut harus didasarkan pada penyantunan semata. ${ }^{5}$

Tujuan pengangkatan anak antara lain untuk meneruskan keturunan manakala dalam suatu perkawinan tidak memperoleh keturunan, dimana hal ini merupakan motivasi yang dapat dibenarkan, dan salah satu jalan keluar yang positif dan manusiawi terhadap naluri kehadiran seorang anak dalam keluarga setelah bertahun-tahun belum dikaruniai anak. Selain itu juga bertujuan untuk menambah jumlah keluarga, dengan maksud agar si anak angkat mendapat pendidikan yang baik, atau untuk mempererat hubungan keluarga. Sisi lain juga merupakan suatu kewajiban bagi orang yang mampu terhadap anak yang tidak mempunyai orang tua, sebagai misi kemanusiaan dan pengamalan ajaran agama. $^{6}$

Adapun dalam hal masalah pewarisan, anak angkat hanya berhak menerima wasiat yang ada kaitannya dengan harta peninggalan orang tua angkatnya, sebagaimana diatur dalam Pasal 209 ayat (2) yang berbunyi "terhadap anak angkat yang tidak menerima wasiat diberi wasiat wajibah sebanyakbanyaknya $1 / 3$ dari harta warisan orang tua angkatnya." ${ }^{\prime 7} \mathrm{Hal}$ ini dilakukan karena atas dasar rasa kasih sayang orang tua terhadap anak, dan juga rasa terimakasih karena semasa hidup orang tua angkatnya, si anak telah berbuat baik menemani orang tua angkatnya, oleh karena itu Islam sama sekali tidak menutup kemungkinan anak angkat mendapat bagian dari harta peninggalan orang tua angkatnya.

Melihat ketentuan diatas, jelas bahwa anak angkat hanya dalam hal pemeliharaannya dan pendidikannya saja yang beralih dari orang tua kandung kepada orang tua angkat, akan tetapi untuk masalah perwalian dalam pernikahan dan masalah waris, anak angkat tetap saja berhubungan dengan orang tua kandungnya, tetapi apabila orang tua angkatnya ingin memberikan warisan kepada anak angkatnya tersebut, maka pemberiannya dilakukan dengan hibah atau wasiat wajibah yang ditulis atau diucapkan oleh ayah angkatnya semasa hidupnya. ${ }^{8}$

\footnotetext{
${ }^{5}$ Muderis Zaini, Op. Cit., hlm. 50

${ }^{6}$ Masjfuk Zuhdi, Masail Fiqhiyah, (Jakarta: Toko Gunung Agung, 1997), hlm. 31

7 Roihan A Rasyid, Kompilasi Hukum Islam Dan Peradilan

Agama Dalam Sistem Hukum Nasional, (Jakarta: Logos

Wacana Ilmu, 1999), hlm. 82

${ }^{8}$ Ahmad Kamil \& Fauzan, Op. Cit., hlm. 102
} 
Kompilasi hukum Islam yang sekarang menjadi acuan oleh pengadilan agama, bahwa anak angkat berhak memperoleh wasiat wajibah dengan syarat tidak boleh lebih dari $1 / 3$ (sepertiga) harta. Menurut Pasal 209 ayat (1) dan (2) KHI, anak angkat ataupun orang tua angkatnya berhak mendapatkan wasiat wajibah sebanyak-banyaknya $1 / 3$ (sepertiga), apabila anak angkat atau orang tua angkatnya tidak menerima wasiat, maka dengan demikian wasiat wajibah adalah merupakan jalan keluar dari pada anak angkat atau orang tua angkat untuk mendapatkan bagian dari harta peninggalan tersebut, namun masalah ini banyak masyarakat umum yang belum mengetahui dan belum memahami kedudukan wasiat wajibah yang sebenarnya.

Menurut ketentuan pasal tersebut di atas, bahwa harta warisan seorang anak angkat atau orang tua angkat harus dibagi sesuai dengan aturannya yaitu dibagikan kepada orang-orang yang mempunyai pertalian darah (kaum kerabat) yang menjadi ahli warisnya. Berdasarkan aturan ini orang tua anak atau anak angkat tidak akan memperoleh hak kewarisan, karena dia bukan ahli waris. Dalam $\mathrm{KHI}$ orang tua angkat secara serta marta dianggap telah meninggalkan wasiat (dan karena itu diberi nama wasiat wajibah) maksimal sebanyak $1 / 3$ (sepertiga) dari harta yang ditinggalkan untuk anak angkatnya, atau sebaliknya anak angkat untuk orang tua angkatnya, dimana harta tersebut dalam sistem pembagiannya bahwa sebelum dilaksanakan pembagian warisan kepada para ahli warisnya, maka wasiat wajibah harus ditunaikan terlebih dahulu.

Menurut ketentuan ajaran syari'ah, keberadaan anak angkat itu tidak dapat dipungkiri, akan tetapi sebatas untuk memberi kesejahteraan dan pedidikan kepada anak. Hal-hal yang tidak diperkenankan adalah memutuskan hubungan darah antara si anak kandung dengan orang tua kandung, sehingga segala akibat dari hak mewarisi gugur karena tidak adanya nasab. Namun demikian sebaiknya anak angkat diberikan wasiat, akan tetapi apabila tidak ada wasiat maka anak angkat tersebut akan mendapat wasiat wasibah sebanyak-banyaknya $1 / 3$ (sepertiga) bagian dari harta warisan orang tua angkatnya. Dengan demikian bahwa anak angkat tetaplah anak dan tidak menyebabkan adanya sebab pernasaban yang merupakan salah satu adanya hak mewarisi. $^{9}$

Peranan notaris sangat penting dalam membantu menciptakan kepastian dan perlindungan hukum bagi masyarakat, karena notaris sebagai pejabat umum berwenang untuk membuat akta otentik, sejauh pembuatan akta otentik tersebut tidak dikhususkan bagi pejabat umum lainnya. Kepastian dan perlindungan hukum itu tampak melalui akta otentik yang dibuatnya sebagai alat bukti yang sempurna di pengadilan. Alat bukti sempurna karena akta otentik memiliki tiga kekuatan pembuktian yaitu kekuatan pembuktian lahiriah (uitwendige bewijsracht), kekuatan pembuktian formal (formele bewijskracht) dan kekuatan pembuktian material (materiele bewijskracht). Mengingat bahwa notaris dianggap sebagai profesi yang terhormat karena bertugas melayani kepentingan masyarakat umum. Kedudukan yang terhormat memberikan beban dan tanggungjawab bagi setiap notaris untuk menjaga wibawa dan kehormatan profesi notaris. Wibawa dan kehormatan profesi notaris dalam menjalankan tugas jabatan sebagai pejabat umum harus dijaga, karena itu diperlukan aturan-aturan yang mengatur, membatasi dan menjadi pedoman bagi notaris dalam melaksanakan jabatan serta berperilaku. ${ }^{10}$

Jabatan notaris merupakan jabatan kepercayaan, harus sedemikian rupa mengatur kewajiban notaris secara seksama dan mendalam. Dalam menjalankan jabatannya, notaris berkewajiban senantiasa melandasi diri pada standar etika yang tinggi, baik yang ditentukan oleh undangundang maupun kode etik organisasi notaris. Pembuatan akta wasiat wajibah bagi anak angkat merupakan bentuk akta yang dibuat di hadapan (ten overstaan) notaris atau dinamakan akta partij" (partij akten). Dalam akta partij ini, dicantumkan secara otentik keterangan-keterangan dari orang-orang yang bertindak sebagai pihak-pihak dalam akta tersebut. Termasuk di dalam akta partij antara lain akta-akta yang memuat perjanjian hibah, jual beli, kuasa, dan lain sebagainya. Pembuatan akta wasiat wajibah bagi anak angkat ini harus berdasarkan kepada keotentikan sebuah akta, yang mana harus memenuhi syarat-syarat yang diatur dalam undang-

\footnotetext{
${ }^{9}$ Achmad Rustandi \& Muchjidin Effendi, Komentar UndangUndang Nomor 7 Tahun 1989, Tentang Peradilan Agama Dan Kompilasi Hukum Islam, (Jakarta: Nusantara Press, 1991), hlm. 27

${ }^{10}$ Ibid., hlm. 37
} 
undang, mengenai keabsahan dan kelengkapan dalam pembuatan sebuah akta otentik.

Notaris selain bertanggung jawab dalam membuat akta wasiat wajibah juga bertanggung jawab dalam pelaksanaannya. Pada pelaksanaan wasiat wajibah ini notaris harus melaksanakan apa yang di kehendaki pewaris atau pewasiat dan menjelaskan semua yang diwasiatkan pewaris kepada seluruh ahli waris, hal ini dimaksudkan agar memberikan kejelasan dan kepastian hukum bagi seluruh ahli waris mengenai hal-hal pelaksanaan wasiat yang diwasiatkan pewaris bagi seluruh ahli warisnya. Sebuah akta notaris yang dipersoalkan di depan sidang pengadilan dalam perkara perdata dengan akta yang dibuat oleh notaris, lebih tepat jika menghadirkan seorang notaris yang membuat akta tersebut sebagai saksi ahli. Kehadiran notaris yang membuat akta yang dijadikan alat bukti dalam suatu perkara bukan sebagai saksi biasa melainkan sebagai saksi ahli yang akan menerangkan tentang apa yang saksi ketahui menurut keahlian saksi, berkaitan dengan prosedur baku terbitnya sebuah akta notaris. ${ }^{11}$

\section{Kewenangan Notaris dalam Pembagian Waris hanya terbatas pada Waris Barat dan Pembagian Waris Islam tidak ditugaskan kepada Notaris.}

Berdasarkan undang-undang nomor 2 tahun 2004 perubahan undang-undang nomor 30 tahun 2004 tentang jabatan notaris, pasal 15 ayat 1 disebutkan bahwa "Notaris berwenang membuat akta autentik mengenaisemua perbuatan, perjanjian dan ketepatan yang diharuskan oleh peraturan perundang-undangandan/atau yang dikehendaki oleh yang berkepentingan untuk dinyatakandalam akta autentik, menjamin kepastian tanggal pembuatan akta, menyimpan akta dan memberika grosse, salinan dan kutipan akta, semuanya itu sepanjang pembuatan akta-akta itu tidak juga ditugaskan atau dikecualikan kepada pejabt lain atau oranglain yang ditetapkan oleh undang-undang".

Pasal 16 ayat (1) hruf e, menyatakan bahwa "notaris wajib memberikan pelayanan sesuaidengan ketentuan undang-undang ini, kecuali ada alasan untuk menolaknya".

\footnotetext{
${ }^{11}$ Pricilia Yuliana Kambey, Peran Notaris Dalam Proses Peradilan Pidana, (Jurnal, Lex Et Societatis, Volume I Nomor 2, April - Juni, 2013), hlm. 30
}

Kedudukan Notaris dan PPAT mempunyai kaitan
erat dengan pelaksanaan pembagian harta peinggalan secara damai (diluar pengadilan/ non ligitasi) terhadap orang yang tunduk terhadap Hukum Perdata Barat (BW) maupun orang islam yang tunduk terhadap hukum islam. Apabila selama ini berkembang anggapan umum bahwa profesi notaris hanya melayani mereka yang tunduk kepada Hukum perdata Barat (BW) saja, sebenarnya hal itu tidak selalu benar. Setelah berlakunya UndangUndang Perkawinan, Undang-Undang Peradilan Agama, Amandemen UUPA, dan KHI, tugas Notaris pada bidang kekeluargaan dan kewarisan yang diatur dalam UU No 1 tahun 1974 dan KHI diantaranya sebagai berikut :

1. Pasal 29 undang-undang nomor 1 tahun 1974, yaitu membuat perjanjian perkawinan.

2. Pasal 195 ayat (1) kompilasi hukum islam yaitu wasiat dilakukan secara lisan dihadapan dua orang saksi atau dihadapan notaris. Disini notaris diberikan kewenangan untuk membuat akta wasiat.

3. Pasal 195 ayat (4) kompilasi hukum islam yaitu pernyataan persetujuan ayat (2) dan (3), pasal ini dibuat secara lisan dihadapan dua orang saksi, atau ditulis dihadapan dua orang saksi atau dihadapan notaris.

4. Pasal 199 ayat (2) kompilasi hukum islam yaitu pencabutan wasiat dapat dilakukan secara lisan dengan disaksikan oleh dua orang saksi atau ditulis dengan disaksikan oleh dua orang saksi atau berdasarkan wasiat notaris terdahulu dibuat dihadapan notarisberupa akta notaris.

5. Pasal 199 ayat (3) kompilasi hukum islam yaitu jika wasiat dibuat secara tertulis, maka bisa dicabut secara tertulis dengan disaksikan oleh dua orang saksi atau berdasarkan akta notaris.

6. Pasal 199 ayat (4) kompilasi hukum islam yaitu bila wasiat dibuat berdasarkan akta notaris, maka hanya dapat dicabut berdasarkan akta notaris.

Dalam pasal-pasal tersebut jelas disebutkan bahwa notaris memiliki peran yang penting dalam hubungan kekeluargaan khususnya bagi orang yang beragama islam. Mengenai pembagian harta warisan menurut hukum islam. Pelaksanaannya dapat dilakukan oleh ahli waris dan didampingi oleh notaris, dengan penjelasan sebagai berikut :

1. Pembagian harta peninggalan (harta warisan) yang dilakukan oleh para ahli waris (pasal 187 dan 188 kompilasi hukum islam) umumnya masyarakat membagi sendiri harta peninggalan 
pewaris sesuai dengan kehendak dan keiinginannya sendiri. Pembagian semacam ini terkadang menimbulakn masalah. Kemungkinan yang bisa terjadi yaitu unsur subjektifitas, padahal kesepakatan dan kerelaan para ahli waris yang menjadi acuan dalam pembagian harta warisan.

2. Pembagian harta peninggalan yang dilaksanakan oleh para ahli waris dihadpan notaris berupa akta waris.

Pembagian warisan dalam islam telah begitu jelas diatur dalam Al Qur'an diantaranya yaitu pada surah An-nisa' ayat 11, 12, dan 76 dan juga dalam hadits-hadits. Pembagian harta ini pun bertujuan agar diantara manusia yang ditinggalkan tidak terjadi perselisihan dalam membagikan harta waris. Namun, sebelum harta waris itu diberikan kepada ahli waris, ada suatu hal yang terlebih dahulu mesti dikeluarkan, yaitu peninggalan dari orang yang meninggal tersebut. $^{12}$

Didalam isi akta pemisahan dan pembagian harta warisan dibuat secara autentik dihadap notaris tersebut dijelaskan bahwa para penghadap pada saat penandatangan akta tersebut telah mengetahui hak bagian warisan masing-masing menurut syariat islam dan bersepakat melakukan pembagian dan pemisahan harta warisan ini dengan penuh keihklasan dan keridlaan masing-masing, akan tetapi didalam akta tidak dijelaskan secara rinci berapa besar hak dan bagian masing-masing ahli waris sebelum diakan pembagian menurut kesepakatan semua ahli waris.

Terjadinya peralihan hak-hak kebendaan sebagai akibat dari pewarisan adalah merupakan peristiwa hukum yang pelaksanaannya memerlukan bukti-bukti yang menunjukan bahwa ahli waris adalah pemegang sah untuk menerima harta warisan dari pewaris. Oleh karena itu, bukti-bukti harus dikeluarkan oleh pejabat umum/ instansi pemerintah atau lembaga peradilan yang berwenang menurut undang-undang. Notaris berdasarkan perundangundangan merupakan pejabat umum yang berwenang mengeluarkan akta autentik, salah satunya adalah akta pemisahan dan pembagian harta warisan. Pada dasarnya semua telah diatur oleh Allah SWT dalam Al-Qur'an maupun Al-Hadist seperti halnya mengenai hukum-hukum yang mengaturtentang hukum kewarisan bagi umat muslim harus dilaksanakan sesuai yang telah diatur tersebut.

\footnotetext{
${ }^{12}$ Sayyid Sabiq, $1997: 452$
}

Namun dalam praktek kehidupan sehari-hari seringkali tidak sesuai dengan apa yang diatur didalam Al-Qur'an maupun Al-Hadist. Hal tersebut karena alasan yang berbeda dari masing-masing ahli waris. Banyak sekali yang melaksanakan pembagian warisan dengan prinsip kekeluargaan berdasarkan kesepakatan dari ahli waris.

Jabatan notaris diadakan oleh hukum dengan maksud untuk membantu dan melayani masyarakat yang membutuhkan alat bukti tertulis yang bersifat autentik, mengenai keadaan, peristiwa, atau perbuatan hukum. Notaris sebagai pejabat yang umum berwenang membuat akta autentik diantara nya mengenai semua perbuatan dan perjanjian seperti yang diatur didalam Pasal 15 ayat (1) undang-undang nomor 2 tahun 2014 atas perubahan undang- undang nomor 30 tahun 2004 tentang jabatan notaris asal tidak bertentangan dengan unsur-unsur dan syarat sah nya perjanjian dalam pasal 1320 KUHPerdata dan syarat sahnya serta rukun-rukun perjanjian (akad) menurut hukum islam. Kewenangan notaris dalam membuat akta pembagian warisan menurut ketentuan hukum islam. Mengacu dari isi pasal 15 ayat (1) undang-undang nomor 2 tahun 2014 atas perubahan undang-undang nomor 30 tahun 2004 tentang jabatan notaris, telah jelas dimana letak yang dimiliki seorang notaris. Walopun merupakan kewenangan secara umum, dengan demikian notaris dapat membuat akta pembagian warisan berdasarkan ketentuan hukum islam pula, yang bisa berpedoman pada ketentuan hukum islamyang terdapat pada Al-Qur'an, Al-Hadist dan kompilasi hukum islam.

Berdasarkan undang-undang jabatan notaris, notaris mempunyai wewenang untuk membuat akta autentik yang mempunyai kekuatan mengikat, dan mempunyai kekuatan yang sempurna jika dijadikan sebagai bukti. Namun jika tidak sesuai dengan prosedur yang ditetapkan oleh undang-undang maka akibat hukumnya, akta notaris tersebut hanya mempunyai kekuatan hukum sebagai akta dibawah tangan dan atau batal demi hukum, yang pembuktiannya harus dibuktikan melalui proses gugatan perdata di pengadilan yang diajukan oleh pihak yang namanya tercantum dalam akta dan menderita kerugian sebagai akibat dari akta tersebut. Akta yang dibuat dihadapan notarisbentuknya sudah diatur dalam undang- undang nomor 30 tahun 2004 tentang jabatan notaris dan undang-undang nomor 2 tahun 2014 atas perubahan undang- undang nomor 30 tahun 2004 tentang jabatan notaris. Oleh karena 
itu, agar bisa dijadikan sebagai alat bukti, setiap perjanjian atau perikatan hendaknya dibuat secara tertulis. Dengan menuangkan keinginan yang hendak diperjanjikan kedalam suatu perjanjian yang dibuat dalam bentuk tulisan agar dikemudian hari tidak ada yang memungkiri dengan apa yang telah di sepakati bersama dalam perjanjian atau kesepakatan.

Selama ini para pejabat hukum di Pengadilan Agama belum mengetahui bagaimana membagi harta peninggalan secara profesional sebagaimana yang telah dilaksanakan Notaris berdasarkan pasal 1074 KUHPerdata dan pasal-pasal yang ada didalam UUJN. Sedangkan para Notaris mempunyai anggapan bahwa pembagian harta peninggalan adalah wewenang Hakim Pengadilan Agama. Disini penulis menyimpulkan bahwa telah ada kekosongan hukum yang belum terisi tentang siapa yang sebenarnya membagi harta peninggalan secara profesional. Maka banyak dari sebagian Notaris yang sudah berpengalaman dan profesional ingin mengetahui mengapa kewenangan pembagian harta peninggalan yang berwenang oleh pengadilan agama tidak ditugaskan kepada Notaris.

\section{PENUTUP}

\section{Kesimpulan}

1. Kewenangan Pertanggung jawaban notaris dalam pembuatan akta wasiat wajibah atas bagian anak angkat tetap mengikuti ketentuan dalam pasal 16 UUJN Undang-Undang No 2 Tahun 2014 Tentang Jabatan Notaris. Pasal 16 UUJN ini membuat ketentuan tentang syarat-syarat bagi notaris dalam membentuk suatu akta, jika salah satu syarat sebagaimana dimaksud tidak dipenuhi, akta yang bersangkutan hanya mempunyai kekuatan pembuktian sebagai akta dibawah tangan. Notaris yang melanggar ketentuan tersebut dapat dikenai sanksi berupa peringatan tertulis, pemberhentian dengan tidak hormat. Selain dikenai sanksi tersebut pihak yang menderita kerugian untuk menuntut penggantian biaya, ganti rugi, dan jika terbukti notaris melakukan pelanggaran terhadap UUJN seperti memalsukan identitas para pihak, memalsukan tandatangan, maka notaris dapat dimintai pertanggung jawaban secara pidana. Anak angkat akan dapat memperoleh harta dari orangtua angkatnya berdasarkan wasiat yang besarnya tidak boleh melebihi $1 / 3$ (sepertiga) harta orang tua angkatnya yang telah meninggal dunia, bila orang tua angkatnya tidak meninggalkan wasiat maka dapat diberi berdasarkan wasiat wajibah, dan pemberi wasiat wajibah tidak boleh merugikan hak-hak dari ahli waris. Kalau anak angkat mendapatkan bagian wasiat wajibah yang melebihi $1 / 3$ bagian, maka wasiat wajibah tidak batal demi hukum, melainkan harus dibatalkan dengan putusan pengadilan.

2. Kewenangan notaris dalam pembagian waris hanya terbatas pada waris barat (BW) dan mengapa pembagian waris islam tidak ditugaskan kepada notaris. Notaris memiliki kewenangan dalam pembagian waris islam tetapi menurut Notaris Sri Rochayati yang memiliki kewenangan penuh untuk menetapkan pengakuan dan pemutusan secara hukum adalah pengadilan. Notaris dalam pembagian warisan berperan dalam pembuatan Akta Pernyataan Waris dan Surat Keterangan Hak Waris. Apabila terjadi sengketa, Notaris dapat membuatkan akta-akta perdamaian dan/atau perjanjian pelepasan hak tuntutan.

\section{Saran}

1. Sebaiknya notaris dalam melaksanakan setiap pembuatan akta wajibah lebih mementingkan kepentingan bersama dari pada kepentingan satu pihak, sehingga keberadaan masing-masing pihak tidak terabaikan dan mendapatkan kedudukan yang seimbang, namun jika dalam wasiat wajibah para ahli waris menyetujui lebihnya bagian anak angkat, maka notaris harus mencatat itu didalam aktanya, dan jika tidak disetujui pihak ahli waris maka notaris harus mempertanggungjawabkan perbuatannya.

2. Notaris harus memegang kendali betul dalam pembuatan akta pembagian warisan yang berkenaan dengan tugas dan kewenangan notaris. Ketelitian dan kelengkapan pengetahuan mengenai hukum waris seharusnya dikuasai betul oleh Notaris agar tidak terjadi kesalahan dalam pembuatan akta mengingat waris adalah salah satu hukum yang konfliktual mengingat isinya yang berupa harta dan harta di era materialistis ini memegang peran penting bagi kelangsungan hidup manusia ke depan. Hal ini untuk meminimalisasi kesalahan notaris yang bukan tidak mungkin bisa dibawa ke pengadilan oleh pihak-pihak yang bersangkutan. Oleh karena itu sebelum terlambat, Notaris harus mempersiapkan 
semua hal dengan teliti dan mengetahui hukum waris yang berlaku di Indonesia.

\section{DAFTAR PUSTAKA}

Achmad Rustandi \& Muchjidin Effendi, Komentar Undang-Undang Nomor 7 Tahun 1989, Tentang Peradilan Agama Dan Kompilasi Hukum Islam, (Jakarta: Nusantara Press, 1991),

Ahmad Azhar Basyir, Kawin Campur, Adopsi, Wasiat Menurut Islam, (Bandung: AlMaa'rif, 1972)

Hukum Nasional, (Jakarta: Logos Wacana Ilmu, 1999)

Masjfuk Zuhdi, Masail Fiqhiyah, (Jakarta: Toko Gunung Agung, 1997
Muderis Zaini, Adopsi Suatu Tinjauan Tiga Sistem Hukum, (Jakarta: Sinar Grafika, 1995),

Pasal 22 Peraturan Jabatan Notaris menyatakan bahwa "Akta-akta Notaris, dibuat dihadapan Notaris, dengan dihadiri dua orang saksi" Pasal 21 P.J.N

Pricilia Yuliana Kambey, Peran Notaris Dalam Proses Peradilan Pidana, (Jurnal, Lex Et Societatis, Volume I Nomor 2, April - Juni, 2013),

Roihan A Rasyid, Kompilasi Hukum Islam Dan Peradilan Agama Dalam Sistem Hukum Nasional, (Jakarta: Logos Wacana Ilmu, 1999

Undang-Undang Nomor 2 tahun 2014 perubahan Undang-Undang Nomor 30 Tahun 2004 Tentang Jabatan Notaris 